\author{
International Journal of Tourism Cities
}

\title{
Communist heritage representation gaps and disputes
}

\begin{tabular}{|r|l|}
\hline Journal: & International Journal of Tourism Cities \\
\hline Manuscript ID & IJTC-03-2017-0015.R2 \\
\hline Manuscript Type: & Research Article \\
\hline Keywords: & $\begin{array}{l}\text { red tourism, communist heritage tourism, Revolution heritage tourism, } \\
\text { User generated contents, Representation, Destination promotion }\end{array}$ \\
\hline \multicolumn{2}{|l}{} \\
\hline
\end{tabular}

SCHOLARONE $^{\text {Im }}$

Manuscripts 


\section{Communist heritage representation gaps and disputes}

Purpose - The aim of the research is to identify and explore how different stakeholders represent communist and revolution heritage for tourism, with a case-study on Bucharest, the capital city of Romania. The research attempts to identify gaps and tensions between representation makers on communist heritage tourism.

Design/methodology/approach - The research employs a range of qualitative methods in order to explore communist heritage tourism representation from different perspectives: content analysis of secondary data in the form of government, industry and media destination promotional material; interviews with a range of representation producers (government, industry, and media); focus groups with potential tourists; and content analysis of user generated content under the form of blogs by actual visitors to Bucharest.

Findings - Findings reveal that there are gaps between the 'official' or government representations of communism and revolution heritage and 'unofficial' or industry, media and tourists' representations. The research confirms and builds on Light's (2000a; 2000b) views that communist heritage is perceived as 'problematic' by government officials and that attempts have been made to reinterpret it in a different light. The process of representation is made difficult by recent trends such as the increase in popularity of communism heritage tourism in countries such as Germany or Hungary. The potential of communist and revolution heritage to generate tourism is increasingly being acknowledged. However, reconciliation with 'an unwanted' past is made difficult because of the legacy of communism and the difficulties of transition, EU-integration, economic crisis, or countless political and social crisis and challenges. The 'official and 'unofficial' representations successfully coexist and form part of the communism and revolution heritage product.

Research limitations/implications - The research attempts to look at the representation of communism heritage from different angles, however, it does not exhaust the number of views and perspectives that exist on the topic. The research only records the British and Romanian perspectives on the topic. The topic is still in its infancy and more research is needed on communism heritage tourism and representation.

Originality/value - The research identifies and explores gaps, agreements and disagreements over the representation of communist and revolution heritage in Bucharest, Romania.

Keywords: Red tourism, Communist heritage tourism, Revolution heritage tourism, Representation, User generated contents, Destination promotion 
Paper type Research paper

\section{Introduction}

The article explores the topic of communist heritage tourism representation, with a case-study on Bucharest, Romania. The topic of how to represent communist heritage for tourism is receiving increasing attention both in academia and the industry as demand and supply for communist heritage tourism products increases. The paper compares and contrasts the representations of communist and revolution heritage from different stakeholders' perspectives: government, tourism media, tourism industry, potential tourists and actual tourists. It looks at 'official' representations under the form of destination promotion material; as well as 'unofficial' representations under the form of communist and revolution heritage promotion by tourism media and industry, and tourist online generated content.

The research looks at these representations in order to identify the potential gaps and tensions that may exist and the reasons behind. It is believed that by exploring a range of views a fuller picture of the phenomena can be identified. Its originality consists in the analysis of destination materials, user generated content and the views of potential tourists, practitioners and policy makers. It can be as source of valuable information for industry practitioners and policy makers looking to understand and develop communist heritage in a Central and Eastern European context.

The representation of communist heritage within a capital cities context is of particular importance as they are gateways to the country. By their very nature, capital cities are administrative, political, cultural, financial, and tourism hubs (Maitland, 2010). Cities that have been subjected to such an intense process of transformation such as Central and European capitals need to be investigated further: "the cities of Central Europe have long been the heritage showcases that reflected the complex historical and geographical patterns of the region's changing governments and ideologies" (Ashworth and Tunbridge, 1999:105). Stanilov (2007) points out that the metamorphosis from communist to capitalist has reshaped the lifestyles, atmosphere and built environment of CEE cities. Complex issues such as national and identities, heritage perception and interpretations have to be addressed (Ratz et al, 2008), especially when entering the global tourism competition meant adapting to Western the pressures of being perceived as a dynamic and cosmopolitan urban space. When embarking on this journey many CEE cities perceived that the only way to achieve this was by being free of their socialist past (Czepczynski, 2008; Smith and Puczko, 2010). This 
process of reinterpretation and representation is of interest in this study. The paper starts with a brief justification and overview of gaps in literature around communist heritage and tourism leading up to an outline of the aim and objectives of the current study. The article continues with a literature review of relevant theories and the explanation of the methods and fieldwork conducted. It then presents the analysis and discussion of key findings and finishes with the conclusions and recommendations.

\section{Communist heritage and tourism: concepts and gaps}

Duncan Light is one of the first scholars to register the "tourists' interest in the 'heritage' of communism" (Light, 2000b:157). Since then this field has grown, especially in terms of tourist numbers. Our understanding of communist heritage in relation to tourism is very much limited; the field is still in its infancy and under-researched. The lack of agreement on terminology, the wide geographical distribution of communist heritage, the complexity and diversity of the heritage itself, the sensitive nature of communism as a political ideology, the traumatic events that led to and surrounded the fall of communism in some countries, the societal and personal emotional baggage associated with communism, or the negative legacies of communism may be some of the reasons why the topic has not received as much attention in academic literature. More research is needed in order to understand the drivers and inhibitors to communist heritage tourism development.

The heritage of communism is being studied under many names depending on the location and historical, social and political context of the research (please see Table 1). 'Communist heritage tourism' is the term often used when talking about the communist heritage of Central and Eastern European (CEE) countries, also known as the former Eastern Bloc (for example Light, 2000a; Light, 2000b; Dujisin, 2007; Light and Dumbrãveanu, 1999; Bucica, 2002; Ivanov, 2009; Maitland, 2010; Light and Young, 2011; Iankova, 2013; Todorova and Gille (2013); Todorova et al (2014); Park (2014); Ivanova, 2017). 'Red tourism' is another term associated with the study of communist heritage but it is mainly used in relation to East Asian countries; some are current communist countries such as: China, North Korea, Laos, Vietnam, and others are former communist countries such as Cambodia (for example Henderson, 2007; Li and Hu, 2008; Li et al, 2010; Zhao and Timothy, 2015; Zhao and Timothy, 2017). Socialist and totalitarian tourism are also terms occasionally used when discussing the heritage of the communist period (for example Backvarov, 1997; Zubak, 2005; Kuusi, 2008). 
There is a lack of comparative studies between communist heritage tourism and red tourism. Most comparative work is conceptual (for example Caraba, 2011). Very little attention has been paid to the differences and similarities between communist heritage and tourism in different countries either. Light (2000b) does it for a few CEE countries and Henderson (2007) for a few East Asian countries; however, at this stage no primary research could be identified comparing East European and East Asian countries in relation to communist heritage and tourism.

Caraba (2011) summarises some of the conceptual differences between 'red tourism' and 'communist heritage tourism' (see Table 2). The object of the tourist gaze does present some differences, while "both types use communist heritage sites as primary tourism resources", however, "Red Tourism focuses on sites related to the beginning of communism in China and to the Chinese Revolution, communist heritage tourism in linked to sites that remind of the communist past of the states of CE Europe" (Caraba, 2011:38).

A second area of differentiation is planning and development: "In terms of planning and development Chinese Red Tourism is entirely run by the State (major investments in infrastructure and facilities and discounts for different categories of red tourists), communist heritage tourism in CE Europe evolved due to external demand for communist heritage sites" (Caraba, 2011:38). Zhao and Timothy (2015:489), for example, looked at the formal and informal structures, networks ('guanxi'), and mechanisms governing communist heritage tourism development in China and argued that the government's main roles are both "topdown (e.g. planner and designer, resource organizer and provider, and coordinator) and bottom-up (e.g. supporter, executor, and guanxi builder and maintainer)”. In CEE countries, the governments do not want be associated with this form of tourism and it is only the industry that reacts to it and creates a communist heritage 'product' and 'package' in response to tourist demand (Light, 2000a; Light, 2000b; Caraba, 2011).

As can be observed from Table 2, the biggest difference between the two types is around image, perception and representation. While one is a celebration of communism, glorifying the past, encapsulating discourses of patriotism and nationalism; the other is the exact opposite, it is a reminder of tough and difficult times, it is ignored or reinterpreted, disputed and hated, and only a tourism attraction in the eyes of the Western 'Other', or the nostalgic residents wishing to remember and relieve the past. It is argued that communist heritage is a difficult topic to investigate because of the fundamentally opposing views taken on it (Figure 1). On a superficial level, this can be attributed to the fact that one form of communist 
heritage is attributed to countries that have rejected and vilified communism; while the other has embraced and glorified it. This hypothesis needs further investigation and both types of communism related tourism need further academic attention.

Although, a deeper investigation reveals that there might be a wider spectrum of different types of communism related heritage tourism (Figure 2). The CEE communist heritage tourism has been developing at a rapid pace with a number of countries and communist heritage attractions emerging such as:

- "Germany - Berlin wall, the divided city

- Poland - Nowa Huta (Steel Mill)

- Hungary - Memento Park (open air museum), House of Terror

- Czech Republic (Prague) - Museum of Communism

- Bulgaria - Museum of Socialist Art” (Iankova and Mileva, n.d.:2)

In addition to this, a number of communist related tourism products are increasing in popularity. In East Germany, for example, a communist heritage related tourism product called 'ostalgie tourism' can be identified. 'Ostalgie' is a German term to describe feelings of nostalgia, curiosity and/or fascination with the communist past.

An example of 'ostalgie tourism' product is:

"German tourists relive the Communist East by spending a night in a Stasi bunker with 'basic training' and authentic military rations (...) Deep in the forests of former East Germany they are spending the night in an authentic Stasi bunker - complete with military uniforms, rations and formal training for a Cold War chemical attack. Teenagers not yet born when the wall fell are among those signing up for the 14-hour tour at the Bunkermuseum Frauenwald, a 38,750 sq ft underground complex which once had enough supplies to last 130 occupants up to a year.” (Bloom, 2014)

Trabant street car races and communist memorabilia are also popular 'ostalgie tourism' activities. The field of 'ostalgie tourism' has received very little academic attention at this stage. More research is needed in order to understand the motivations and experiences of participant in 'ostalgie tourism'. Nostalgia appears to drive older generations of tourists and communist heritage consumers, while younger generations are driven by curiosity. This hypothesis needs to be tested. 'Ostalgie tourism' also needs to be analysed from the supply 
angle, specifically on how attractions and accommodation and catering suppliers are 'constructing' the authenticity of the 'ostalgie tourism' product.

Therefore, there are a number of communism related heritage tourism types and the issue can be analysed from different perspectives: government; demand - actual and potential tourists; supply - attractions, communist heritage themed accommodation and catering; intermediaries - specialised travel agents and tour operators. A number of issues can be analysed:

development; image; marketing and representation; heritage interpretation, conservation and preservation; authenticity and staged authenticity; tourist experience, co-creation and performance. According to Iankova and Mileva (n.d.:2-3), the main issues related to communist (socialist) heritage that have received academic attention are linked to the: "interpretation; the attempt to create the new European image; the negative attitude against the old regime; emotional involvement; politically dependent (ideology), inconvenient (e.g. Nazi period in Germany)". Communist heritage can also be viewed from different angles: during communism (e.g. propaganda, impacts, and lifestyles); after / post-communist angle (legacy). Most research looks at communism heritage from the post-communist perspective reinterpreting the past through the lens of the present and our current understanding of communism, and also through country-specific lenses. As previously argued, there are many gaps in knowledge in relation to this type of tourism.

The biggest question around 'ostalgie tourism' is whether it is a new sub-segment of communist heritage tourism and it reflects changes in perception and representation of communist heritage tourism, or it is a brand new form altogether, completely different and separate from it.

The current research attempts to fill in this gap in knowledge by focusing on how communist heritage is represented in CEE countries and if the increase in popularity of communist related heritage has led to changes in perception and representation. In order to achieve this purpose, the current research adopts a case-study approach and revisits one of the original communist heritage tourism sites analysed in Central and Eastern Europe. Romania and its capital, Bucharest, were the focus of one of the first research projects on communist heritage tourism developed by Light and Dumbraveanu (1999), and Light (2000a; 2000b; 2001).

Romania stands out amongst other CEE countries because the change of regimes was through a violent revolution and any discussion of communist heritage is inevitably accompanied by references to revolution heritage. Revolution heritage in Bucharest refers to those sites that 
were the physical locations where the fighting and violent events of 1989 took place. These locations are on the tourist trail and part of the communist heritage 'experience' in Bucharest. Duncan Light not only defined communist heritage tourism but identified the strong feelings of hatred towards any communism related aspect, arguing that the Western 'Other' is responsible for its development and that this particular gaze is unwanted and uncomfortable for the destination: "the legacy of communism and revolution has become the focus of interest among Western tourists in post-communist Bucharest. It argues that 'communist heritage' tourism the consumption of key sights and sites associated with the Ceausescu regime and its overthrow has emerged as a particular form of cultural or heritage tourism for special interest tourists. However, this is a heritage which is defined and constructed entirely outside Romania. Within Romania itself there is understandably little desire to remember the period of communist rule, and the legacy of this period is powerfully dissonant with the country's post-communist aspirations. Consequently, as a consideration of two case studies illustrates, there is no concern to interpret the legacy of communism for tourists; instead there is an attempt to deny or airbrush out this period of the country’s history" (Light, 2000a:145).

The current research wishes to build and add to that debate by looking at the representation of communist and revolution heritage tourism in Bucharest from different angles, comparing and contrasting them. It is guided by a number of research questions:

- How do textual and visual destination materials and user generated content represent Bucharest in terms of communist and revolution heritage tourism and are there any differences in perceptions and representations?

- Why do these destination representations of communist and revolution heritage tourism exist and what factors shape and affect them?

\section{Literature review}

The fall of communism in CEE and the change to capitalism was not an easy process (Ratz et al, 2008). Different countries adopted different approaches: "methods range from the outright banning of Communist parties (later lifted), erasing public images and erecting new monuments in honour of democracy, opening secret police files, lustration and restitution" (Marsh, 2012:1). For post-communist destinations, the transition process was marked by many transformations in its built environment, lifestyles, perceptions and atmosphere with the sole purpose of adapting to a new political identity (Stanilov, 2007); but also in order to leave behind the past and embrace a future free of socialism. In their desire to reinvent and 
change their images into dynamic and cosmopolitan hubs, many cities went to extremes. In order to free themselves of any associations with a communist past, some cities went on destroying communist landmarks or simply rebranding them as capitalist icons (Czepczynski, 2008; Smith and Puczko, 2010).

\section{Communist heritage through a post-communist lens}

How the past is interpreted in the present is a popular topic of discussion for historians and social scientists. Light (2000b) and Czepczynski (2008), both talk about the rejection of the communist past. This rejection is evident in tangible aspects such as infrastructure and built environment, and intangible such as atmosphere and way of life. Different tools and approaches have been used to 'get rid of' the past, from renaming communist buildings to demolishing them completely.

This process of removing the communist past is natural and expected in any nation having gone through traumatic events and wishing to reinvent its identity (Lowenthal, 1995; Ashworth and Tunbridge, 1999; Evans, 2002). The making and un-making of history is a subjective and selective process and history itself is nothing more than as "a narrative discourse, the content of which is as much imagined / invented as found" (White in Jenkins, 1995:134). History can be 'made' and 'un-made' by carefully selecting facts and interpretations, ordering them to make an 'agreeable' narrative and 'selling' it to an audience: "In 'making history', the historian begins with a provisional selection of facts and a provisional interpretation in the light of which that selection has been made - by other historians working in the field as well as by himself/herself. As the historian works on, and as new information (both 'primary and 'secondary') is processed, so both the interpretation and the selection ordering of facts undergoes subtle changes through the reciprocal action of the one on the other. This reciprocal action also involves reciprocity between the present and the past. Thus facts and interpretation, past and present, intermingle in a unity of scholarly duty" (Jenkins, 1995:55).

The history maker is exercising his power and control over it. (Jenkins, 1995). In the case of communism, the greed interpretation of facts and construction of history is that communism is 'bad' and therefore should be put aside as all bad things must. However, at least in theory, power can be held by multiple entities at the same time, each creating its own version of the history. Just because one entity deletes or reinterprets certain events, it doesn't mean that this version will be accepted by everyone. In the case of communism, tourists are not accepting a 
half-deleted, vilified interpretation of history and decide to visit the place in order to actively test their own theories about communism and communist history (Light, 2000a).

In addition to history and its interpretation, another relevant set of debates is around socialist heritage. A number of authors have argued that urban landscape often perfectly represent political ideologies and the physical manifestation of the power of rulers (Light, 2001; Czepczynski, 2008). Communist architecture presents some easily recognisable characteristics in terms of size, building materials used, and intended use. The communist blocs all over Romania, for example, were built to host the 'heroes' of the communist industrial revolution. Taken from their villages or promised work in the city, millions of Romanians relocated and found new homes in small, box-like flats. Most often a family of four would share a one bedroom and one living room acting as a second bedroom. Nevertheless, these blocs were sold as symbols of the working man in aggressive communist propaganda campaigns. This process of transformation of the urban environment according to the communist ideology was often the result of the demolition and destruction of precommunist housing and landmarks (for example, in Bucharest): "The socialist transformation standardised the architecture in Central and Easter Europe (...) monumental planning and representative building in capital cities manifested the new political order" (Kolbe, 2007:84). Communist heritage's interpretation through the post-communist lens is highly complex and is under-researched, especially on the transformation of socialist spaces in the post-socialist era (Stanilov, 2007). The heritage of the city inevitably reflected the complex changes it went through its many decades under communism - "The cities of Central Europe have long been the heritage showcases that reflected the complex historical and geographical patterns of the region's changing governments and ideologies" (Ashworth and Tunbridge, 1999:105). Landmark communist buildings in East Germany, Czechoslovakia, Poland, Hungary, Romania and Bulgaria have been reinterpreted overnight as capitalist landmarks and symbol of the new political ideology (Czepczynski, 2008). The Parliament Palace in Bucharest, for example, was meant to be demolished after the revolution but due to its size and the complicated demolition process, it was rebranded as a testimonial to the craftsmanship and skill of Romanian workers and now houses the parliament.

The tourist gaze is constantly looking for landmarks when visiting cities (Urry, 1990). Imposing, grand buildings or quirky, stand-alone ones always fascinates tourists. When faced with the unknown origins of a landmark the tourist imagination goes to work, "the determination of what the attractions are representations of, is an essential component of the 
tourist discourse" (Suvantola, 2002:169). Modifying or destroying heritage produced by an unwanted part of history may be perceived as a loss from the tourist perspective. Cutting 'the ugly' is normal and a common practice in destinations everywhere (Judd, 1995). However, deciding what is ugly and what is beautiful has always been a subjective process. Especially with today's discourses of "globalisation and homogenization of culture" (Richards, 2007:330) versus originality and 'distinctiveness' (Richards, 2007). Although inconvenient, communist heritage does distinguish post-communist cities from western competitors. Some studies on dark tourism also focus on communist sites; however, to argue communist heritage tourism is part of dark tourism would be unsupported. More research is needed to identify and explore the relationship between dark tourism and communist heritage tourism.

\section{Representing the post-comm unist CEE city for tourism}

After the revolution, CEE cities rushed to enter the global tourism race. CEE cities used western tools to achieve this, such as: "refurbishing run-down areas, touting for conference business, building shopping malls and creating 'carousal' zones” (Judd, 1995:175); or they used a combination of traditional marketing tools such as: image marketing, attractions marketing, infrastructure marketing, and people marketing (Kotler et al., 1993). Communist buildings were left out, ignored, re-branded or demolished. "This process of transformation occurred at a time when tourism has been characterised by flexibility and segmentation in contrast to the mass standardised market of the mid-20 $0^{\text {th }}$ century" (Hughes and Allen, 2005:173). Tourism during communist times took place mostly between the countries of the former communist bloc or under the communist influence (Hall, 1998a; Hall, 1998b; Hughes and Allen, 2005). Tourism in CEE under communism lacked diversity. Popular forms of tourism included: sun and sea tourism, mountain tourism, spa tourism, cultural tourism, religious tourism, or wildlife tourism (Dawson, 1993; Hall, 1998b). However, all CEE countries did have a rich tourist offer. However, most of the tourist infrastructure built during communism was outdated and needed major reinvestments. As a result, most CEE countries went through a complex process of tangible and intangible changes in order to be competitive on a highly competitive tourism market. In addition, privatisation had to be implemented where the ownership of tourist attractions, accommodation and catering went from stateowned to private-owned. The process of re-branding took place on top of this, at all levels: attraction level as well as national level. The purpose of this re-branding process was to represent these countries as tourist attractions for a global audience. During this process, old stories produced by the communist regime were suppressed and replaced by new, post- 
revolution stories representing the new found freedom of these places; effectively, a new reality was constructed for the tourist's imagination: "the fusion of tourist representations and marketing philosophy blurs the boundaries between reality and fiction” (Hughes, 1992:31). Representation is an important practice in tourism and has two sides, a tangible and an intangible one. The tangible is represented by brochures, videos, websites and other textual and visual hard forms (Ward, 1998), while the soft side is represented by the messages transmitted to the public and are often politically charged (Ateljevic and Doorne, 2002:662). It is relevant to study the process of communist heritage representation and to identify if there are gaps between the perceptions and opinions of different actors on it.

\section{Research approach}

The project adopts a multi-method qualitative approach in-line with the social-constructivist paradigm: "Constructivists do not deny the existence of the material world. However, it is not the material world which conveys meaning: it is the language system or whatever system we are using to represent our concepts. It is social actors who use the conceptual systems of their culture and the linguistic and other representational systems to construct meaning, to make the world meaningful and to communicate about the world meaningfully to others" (Hall, 2003b:25). Both qualitative and qualitative approaches can be of used to study representations (for example Stern and Schroeder, 1994; Pritchard and Morgan, 2001; Smith and Puczko, 2012). This study adopts a qualitative framework as it is trying to identify perceptions, opinions and gaps between representations and representation makers.

Multi-method research is ideal when multiple perspectives are being investigated and different data types are needed (Keats, 2000). Table 3 presents and overview of the data collection and analysis methods used. Overall 159 promotional materials and tourist testimonials were collected and analysed in order to identify how communist heritage is represented. Stages 3 and 4 required face-to-face or telephone contact with representation makers in order to identify why these representations exists. This research approach helped identify any gaps between different representation makers.

Data was collected between October 2009 and June 2011. The evolution of communist heritage tourism in Romania has been very slow since data was collected for this study. Official representations have remained unchanged and no new destination promotional campaign has yet been launched. Online however, blogs and Facebook pages are starting to pop up dedicated to communist memorabilia. Facebook page OldRomanianAds, for example, 
reminds its audience of what objects such as juice bottles used to look like or news articles from that time (ReclameVechiRomanesti, 2017). Emerging evidence suggests the phenomenon is expanding and new dimensions are being added to it. As a result, further research is needed.

In terms of sampling, a combination of convenience sampling and snowball sampling was used. Access to the research population for methods 3 and 4 is difficult therefore identifying a few convenient gatekeepers and snowballing from there was a relevant approach (Clark et al, 1998:88).

Content analysis was used to analyse the collected data. "Approaches to content analysis range from the purely quantitative where frequencies are counted within categories through to an approach that focuses on meaning in which inferences are drawn from data and the data is considered in context" (Finn et al, 2000:135). For this qualitative study, content analysis using the qualitative data analysis software NVivo was employed.

This collection and analysis approach was adopted in order to limit researcher bias and minimise the limitation of the study. Qualitative studies are often criticised for being subjective and lacking data comparability. By looking at representations from multiple angles and using different approaches this comparability is made possible. Cross-tabulating between the four stages revealed a number of gaps between the representations of communist heritage by different representation makers and the discourses fuelling them (see Table 4).

\section{Findings and discussion}

There are fewer than expected references to communism and communist heritage in destination promotional materials and tourist testimonials. Representations of communism and communist heritage tend to be mainly negative for all representation makers. Differences are identified mostly in terms of feelings towards it during interviews and focus-groups. Destination materials and their representation makers speak negatively and vilify them; whilst tourists and potential tourists exhibit feelings of fascination with it confirming Lights' (2000a; 2000b) views.

\section{Destination promotion and tourist testimonials representations}

A common theme throughout all destination materials and tourist testimonials is the negative impacts of communism such as lack of freedom, demolition of historic buildings, or censorship. However, these are mostly evident in UK-produced industry and media promotional materials or tourist testimonials. The topic of communism is avoided or ignored 
throughout most government destination promotional materials. Communist history and heritage is presented in an incomplete version or ignored altogether. For example, in an official 2009 official, government-produced representation:

"Legend says that the founder of the settlement which was to become one of the greatest cities of South Eastern Europe was a shepherd named Bucur. The first documented mention of Bucharest dates back to September 20, 1459 and was issued by Prince V1ad the Impaler, the inspiration for the famous Dracula, a hero who has captivated the interest of many enthusiasts. Bucharest has a special charm in that it does not impress through palaces and ultramodern monumental constructions like other metropolises. Instead, it succeeds in captivating through its paradoxes. It is a city where, not long ago, widespread demolitions of historic architecture occurred, and now visitors can see the great "House of the People", a monumental building completed in 1989 which ranks second in the world for its surface area after the Pentagon, and is now home to the present Parliament of Romania. In contrast, the preserved époque buildings of Bucharest... boyars' houses from the mid19th century, public constructions in French neo-classical style, as well as the old parks provide a glimpse into the city's past and create a very elegant atmosphere. Seeing these older remnants of Bucharest's once rich and elegant lifestyle, it becomes easy to understand why until the Second World War, the city was also named "Little Paris".” (Material 2, Romanian National Tourist Office, 2009, Bucharest, Romanian Tourist Office, Ministry for Tourism, printed brochure, page 4).

As it can be seen references are being made to a pre-communist past. Findings confirm existing theories by Lowenthal (1995), Ashworth and Tunbridge (1999) or Evans (2002). In addition, Light (2000b) and Czepczynski's (2008) theories are also confirmed with the palace receiving a capitalist identity. Only one Government material speaks about the communism period but focuses on the industrial development of the city during those times. For example Material 16, Governmental, Bucharest City Hall website talks about the development of the city during communism and is the only government material that details the communist past:

“After the Second World War, the settlement of the "people's power" creates the favourable conditions to appearance of communist's dictatorship which had maintained its power till December 1989. For about 50 years, the real democracy and free market economy were been vanished. Many of applied methods, both in economic and social field, were borrowed from the ancient USSR, didn't take into 
consideration the specific features of the country and of the Capital city, as well. By nationalization process of the main industrial branches, the communist system had offered it the means necessary for the reconstruction and development of the city. Nevertheless, in these last 50 years were built many new industrial plants, new blocks of flats, many social and cultural edifices. There were placed the "industrial giants" and thousands of blocks of flats type "matches box". (...)

The events from December 1989 brought major changes in the Capital city economy, both in structural aspect (decentralization process and ownership type) and of its dynamics.” (Bucharest City Hall website, 2009).

Industry and media promotional material express fascination with the communist regime: "not every industrialization project was a failure: Ceausescu left Romania with a reasonably effective system of power generation and transmission, gave Bucharest a functioning subway, and left many cities with an increase in habitable apartment buildings" (Material 26, Tourism Industry, Romanian travel agents and tour operators).

Communist heritage specialised travel agents could also be identified as far as 2009 when the fieldwork took place. One Bucharest based travel agencies offered communism themed tours:

"Red Bucharest: Let us present to you a different face of Bucharest. Capital of the Socialist Republic of Romania. We will tour the city, pointing the remains of the "Golden Era", while we will lecture you about the good and many bad things that happened during the rule of Ceausescu" (Material 19, Tourism Industry, Romanian travel agents and tour operators).

When talking about the Palace of Parliament. Government, some materials do acknowledge it as Ceausescu's heritage:

"Nicolae Ceausescu's legacy (...) an interesting introduction to the dictator's megalomaniac vision” (Material 5, Governmental, Ministry for Tourism, RoNTO), Its grand size and controversial nature are well acknowledged. So is its tourism appeal and potential. Some sources do acknowledge it as communist heritage:

"The huge investment in its construction and perpetual upkeep makes the Parliament Palace one of the most controversial buildings in the world" (Material 6, Governmental, Ministry for Tourism, RoNTO). 


\begin{abstract}
"Ceausescu draws tourists 20 years after firing squad: Twenty years after his execution by firing squad, the former Romanian dictator Nicolae Ceausescu has become a major tourist draw despite lingering memories of his despotic regime. It is now Romania's top attraction for foreign tourists” (Material 71, Tourism Media, Travel articles).
\end{abstract}

As can be seen above, government materials tend to be critical of it. Media materials, on the other hand are less negative and do not vilify the building, even calling it "big and beautiful" (Material 80, Tourism Media, Travel articles).

The building is both vilified and glorified in most of the 105 destination materials:
"Inspired by the grandiose architecture of North Korea, Ceausescu decided in the Eighties to refashion Bucharest completely by building a vast 'civic centre' district dominated by the 'Palace of the People'. (...) It is grotesque, but utterly compelling" (Material 73, Tourism Media, Travel articles).
"many years after the overthrown of the communist regime, the "House of the People" reminds Romanians of the communist years" (Material 26, Tourism Industry, Romanian travel agents and tour operators)
"Not many Romanians like talking about Nicolae Ceausescu, twenty years after the downfall of the tyrant's despised regime, the memories are too close for comfort" (Material 87, Tourism Media, Travel articles); "building's association with a regime that most Romanians would prefer to forget” (Material 92, Tourism Media, Travel articles).

Analysis of user generated content or tourist testimonials also revealed that the Parliament Palace is the most significant communist heritage, some declaring their fascination while others commenting on the lack of official acknowledgement of the communist past and its impact on the architecture of the city and its Parliament Palace:

"The second biggest building in the world, it can be seen from the moon, which we walked around for an hour, and were not impressed" (Blogger 44).

"Now, it's such a big thing in Bucharest that you really do have to see it. And the interiors are incredible. But bear in mind that you have to go round in a tour, and what you will be told are things along the lines of, "These curtains are 16 feet high and are made of real Romanian silk produced by real Romanian silk worms!” Yep, the people 
who work here are all about the national pride, never mind the fact that 70,000 people were made homeless in the construction of this largely pointless building. So pay your 15lei (a lot of money in Bucharest), observe quietly the ostentation and refrain from asking how many schools and monasteries were wiped out for it. Oh, and don't use the toilets" (Blogger 1)

\section{Representational gaps}

When government, industry, media and potential tourists were asked to 'explain' the existing representations of communism and communist heritage, three gaps could be identified (see Table 4). These three major gaps are about: perception, emotion and action.

'Managing' communism and selling it is difficult mostly because of contradictory perceptions. The topic of communism is approached with weariness and apprehension by government marketers. Although, the government appears to be aware of its potential, it is afraid of what an open acknowledgement and actually selling it might mean. One former minister even openly acknowledged it potential:

"From a tourist point of view, it is extraordinary to exploit the places where the last great dictator of Eastern Europe lived. (...) It is of great interest, people have gotten over their rage about the dictator...For foreigners it is great" (Badea, 2011).

Talk about an official communist tour promoted internationally was recorded. The communist heritage trail would follow the former dictator Nicole Ceausescu's life: starting 150 miles from Bucharest with the old country house where he was born, the prison where he was held a number of times between 1933 and 1944, the palaces he had constructed the country, the Parliament Palace, and ending at the military facility in Targoviste where he was executed with his wife.

The public reactions reflected Romania's apprehension about this project which never did go further. A Romanian historian, Marius Oprea, emphasised that 'selling' Ceausescu as a tourist product will fuel the veneration of those nostalgic for communism and wishing its return (Grigore, 2011). It is well known in Romania that hundreds of people place flowers on the graves of the dictators every month. The historian argued that the government is incapable of producing an agreed representation and blamed it as much on the lack of skill as on the complex nature of the situation (Marius Oprea for NewsIn, 2011). Superstition also appears to be a factor: 
"The Ceausescus were shot on Christmas Day 1989 in a military facility in Targoviste. The building where they were judged and executed is empty to this day, although the military facility is fully operational. What shocks most people is the fact that the outside wall of the building is always wet. Regardless if summer or winter, the stain never dries off. People say the wall is wet because of the tears of Ceausescu who never stops weeping” (Matei, 2011).

Another former tourism minister also argued that too much nostalgic feelings exist about communism to be objective and actually promote it (Grigore, 2011). A survey of 2.184 people revealed that $42.31 \%$ were against and $53.98 \%$ were in favour of promoting communism as a tourist product. (Badea, 2011). However, the survey comments were ironic and frequent references were made about communism being 'better' than democracy and that the country was going through tough times (Badea, 2011).

Current findings confirm Light's (2000a; 2000b; 2001) views that communism and communist heritage is perceived as problematic. The current research also ads to this theory the following: the 25 years after communism are the main reason why communism and communist heritage is not accepted; not the history of communism but the present of democracy. An interesting aspect about Romania is that every December, before Christmas, all news television stations replay the revolution, the events leading up to it, the deaths and the execution. The country appears to be obsessed with that particular moment in time:

"Not only there is no reconciliation with a difficult past but the past itself seems to be constantly 'replayed' in the minds of its citizens due to the many economic difficulties the city and country have been facing" (Sima, 2013:237).

The healing process appears to be taking very complex and unusual forms. Romanians do not appear to view communism as history but as present, and they appear to be, for lack of a better expression, 'stuck in a time loop'. Therefore, promoting communist heritage is a 'tall order'.

As previously mentioned, this comes in conflict with demand. Focus-group results revealed a fascination with communism from potential tourists; some wishing to see how the country developed after 1989 (Focus-group 1, Participants 4 and 6). The focus group included a range of Western and Eastern Europeans as well as participants from non-European countries. Findings reveal that fascination with communism and transition is not a western 
discourse as previously argued (for example Light, 2010a; 2010b). Participants from other eastern countries were equally fascinated:

"I think it should be interesting. I don't know how much of communism is left or is it like here, but I can compare it to China. I've been to Prague and Budapest and I found very little resemblance, but I was told Romania is more Eastern.” (Focus-group 2, Participant 5).

"The first thing I wrote is Eastern Europe and with that communism. (...) I was a big fan of Milan Kundra; he wrote on Eastern Europe and communism. Although not about Bucharest I think. But that's an image I have. Eastern Europe! Communism. And difficult region I think. Very different from the West. At least back then!" (Focus-group 1, Participant 6);

"I don't have strong impressions about Romania. (...) I put Romania in a group of Eastern Europe. I don't have a strong image of Romania. I can't say I differentiate between Eastern countries." (Focus-group 2, Participant 4).

Not all participants associated Bucharest with communist heritage. The study was done two decades after communism and some participants do reflect in their views the desire of the government and the efforts made to re-image the capital into a capitalist, multicultural, westernised city:

"But are there many communist buildings? Because I thought it was westernised. I think it is more Western now. Like lots of small cafes, small streets. Modern, tall buildings, lots of glass. Like Western, historic city. More like Prague.” (Focus-group 1, Participant 1).

This statement sparked some disagreements:

"I don't know... That's where Prague seems different to me to the rest of Eastern Europe. It just seems closer and more Western compared to places like Romania and Hungary and places like that. They seem more Eastern to me than Prague does. And I don't know why but I've got this image in my head like that. Maybe it's advertising. It just seems more like Western Europe - Prague than..., so no I don't think it's like Prague at all.” (Focus-group 1, Participant 5). 


\author{
"I think it's because of the advertisements. Prague...we know about Prague from \\ advertisements, but there are not that many advertisements on Bucharest so we don't \\ really know what it's like." (Focus-group1, Participant1). \\ "There are lots of images of Prague out there aren't there..." (Focus-group1, \\ Participant5). \\ "Seems to be everywhere, very popular city but not Bucharest..." (Focus-group 1, \\ Participant 1).
}

As participants argue, Bucharest still has some mystery around it. Lack of knowledge is evident but this is a selling point. Bucharest appears to be off the beaten tourist map and participants view it as an advantage.

When asked about their opinions about Bucharest as a communist city and communism in general, most participants thought of the revolution and the images televised about it worldwide:

"Should have put shootings, I remember that from the news, he totally deserved it. That was the image they gave us" (Focus-group 1, Participant 5).

“I don't remember anything about there being violence. I don't know if I'm too young..." (Focus-group 1, Participant 7).

"It was a bit like North Africa at the moment" (Focus-group 1, Participant 3). Potential tourists also emphasised that it is normal Romania is rejecting its communist past and that the efforts to promote Bucharest as democratic are valid:

One focus-group participant argued this was made on purpose and the message is to suggest a safe destination, like any other European city so you know what to expect: "I imagine the Romanian tourist board are aware of their own image, they know these things. They know so that to me is a classic...safe...they are trying to tell us they are European, they are safe, you can get around, modern, glass buildings. I don't think it...I don't think it's about us... what we want...I think it's more what they think we need to hear to go there...that they are not too foreign or to alien. There's lots of reassurance in that ad." (Focus-group 1, Participant 3).

The gaps in perception, emotion and action of different representation actors are relevant to undemanding communist heritage representations. This heritage is sensitive in nature and there is no correct way of representing it just as there isn't an agreed representation. Instead, 
it is the contradiction, the complexity and the gaps that appear to be the biggest selling point as 'Focus-group 1, Participant 3' stresses.

\section{Conclusions and recommendations}

In countries such as Romania, communist heritage tourism is still perceived as problematic. In spite of its pull factor for special interest tourists, it is vilified. The last 25 year of democracy are the reason why communism and communist heritage is not accepted or promoted officially by the country's national tourism office. Evidence from four different research stages revealed that it is the present not the past that is making it problematic. Romania has not had a 'good time' and has been facing many political, social and economic crises; as a result a high degree of nostalgia of the stability of those times exists. One of the limitations of the study is that it does not focus its efforts on locals. More research is needed focusing on locals - on those that have experienced communism and those that have not. The stories of locals on communism and communist heritage tourism would provide valuable insight into why and how is communist heritage perceived and if it could be accepted officially as a tourism assets.

The gaps reveal some interesting dimensions of communist heritage however its rejection by officials also means that it does not enjoy any protection and is subject to time. As Caraba (2011) and other communist heritage scholars argue, communist heritage needs to be acknowledged as heritage. Efforts need to be made to manage it, to preserve it and conserve it. Otherwise, it will be damaged or destroyed, or modified beyond recognition just like it has happened to other heritage in the past. More research is needed on how communist heritage is deteriorating and transforming and what is needed in order to reserve it for future generations.

The three gaps need to be closely monitored and more research is needed on how they are changing and mapping out the process of communist heritage representation. This topic has potential for more depth and requires further investigation, covering more CEE countries and comparing gaps between them. This field is still in its infancy. As we move further and further away from the year communism fell in CEE, we will experience an increase in the need to talk about communist heritage and tourism.

The research does have implications for policy and practice. Findings suggest that the field is attracting tourists and therefore industry practitioners could gain insights into how they can better target communist heritage tourists. Findings could also be used for policy making. As 
the article argues, there are tensions between the different representation makers. Navigating these troubled waters and reaching consensus can only be done by gaining a deeper understanding of the phenomena. Research such as this and others like it could potentially help policy makers negotiate and design a communism heritage tourism product that would be tolerated or accepted by all parties involved.

\section{Author details:}

Claudia Sima, $\mathrm{PhD}$, is a Lecturer in Tourism with University of Lincoln. She finished her PhD with University of Westminster in 2012, supervised by Professor Emeritus Robert Maitland and Dr. Andrew Smith.

\section{References:}

Ashworth, G. J. and Tunbridge, J. E. (1999), “Old cities, new pasts: heritage planning in selected cities of Central Europe”, Geo Journal, Vol. 49, pp. 105-116.

Ateljevic, I. and Doorne, S. (2002), "Representing New Zealand: tourism imagery and ideology", Annals of Tourism Research, Vol. 29 No. 3, pp. 648-667.

Backvarov, M. (1997), "End of the model? Tourism in post-communist Bulgaria”, Tourism Management, Vol. 18 No. 1, pp. 43-50.

Badea, C. (2011), “The tourist circuit 'Ceausescu' is a successful idea - Survey / Circuitul turistic 'Ceausescu' este o idee de success - sondaj”, Ziare/Papers, Monday 29 August 2011 at 15:22, available at: http://www.ziare.com/nicolae-ceausescu/comunism/circuitul-turisticceausescu-este-o-idee-de-succes-sondaj-1117103 (accessed 20 March 2012).

Boom, D. (2014), “The real Lives of Others: German tourists relive the Communist East by spending a night in a Stasi bunker - with 'basic training' and authentic military rations (but they escape to a sauna at the end)", Daily Mail Online, 9 November 2014, available at: http://www.dailymail.co.uk/news/article-2799164/the-real-lives-german-tourists-relivecommunist-east-spending-night-stasi-bunker-basic-training-authentic-military-rations-escapesauna-end.html (accessed 27 February 2017).

Bucica, C., (2002), "Legitimating power in capital cities. Bucharest - continuity through radical change ? / Pratiques de légitimation du pouvoir dans la ville capitale. Bucarest: 
continuité dans la rupture", Bucica, C. et Simard, N. (eds.) L'identité. Zones d'ombre, Québec, Les Cahiers du CÉLAT, 171-191, available at: www.hks.harvard.edu/kokkalis/GSW5/bucica.pdf (Accessed 2 November 2008).

Caraba, C.C. (2011), "Communist Heritage Tourism and Red Tourism: Concepts, Development and Problems", Cinq Continents, Vol. 1 No. 1, pp.29-39.

Clark, M., Riley, M., Wilkie, E. Wood, R. (1998), Researching and writing dissertations in hospitality and tourism, Thomson Business Press, Reading.

Czepczynski, M., (2008), Cultural landscapes of post-socialist cities: representation of Powers and Needs, VT: Ashgate, Aldershot-Burlington.

Dawson, A. H. (1993), A geography of European integration, Belhaven Press, London. Dujisin, Z. (2007), "Forget communism ... or sell it”, Global Perspectives, AugustSeptember 2007, available at: http://www.globalperspectives.info/download/2007/pdf/ausgabe_08-09_07.pdf (Accessed 2 February 2016). Evans, E.J. (2002), "Prologue: What is history now? - now", Cannadine, D. (ed.) What is history now? Palgrave Macmillan, New York, pp. 1-18.

Finn, M., Elliott-White, M., Walton, M. (2000), Tourism and leisure research methods: Data collection, analysis and interpretation, Longman, Essex.

Grigore, A. (2011) “Udrea 'resurrects communism': Ceausescu, Romania's newest tourist attraction / Udrea 'reinvie comunismul': Ceausescu, noua atractie turistica a Romaniei”, Business24, Wednesday, 17 August 2011 at 14.53, available at: http://www.business24.ro/dan-matei-agathon/stiri-dan-matei-agathon/udrea-reinviecomunismul-ceausescu-noua-atractie-turistica-a-romaniei-1494573 (accessed 20 March 2012).

Hall, D. (1998a), "Central and Eastern Europe: Tourism, development and transition”, Williams, A. and Shaw, G. (eds.) Tourism and Economic Development: European experiences, third edition, Wiley, London, pp. 345-373.

Hall, D. (1998b), “Tourism development and sustainability issues in Central and Eastern Europe", Tourism Management, Vol. 19 No. 5, pp. 423-431.

Henderson, J. C. (2007), “Communism, heritage and tourism in East Asia”, International Journal of Heritage Studies, Vol. 13 No. 3, pp. 240-254. 
Hughes, G. (1991), “Tourism and the geographical imagination”, Leisure Studies, Vol. 11 No. 1, pp. 31-42.

Hughes, H. and Allen, D. (2005), "Cultural tourism in Central and Eastern Europe: the views of 'induced image formation agents"”. Tourism Management, Vol. 26, pp. 173-183.

Iankova, K., (2013), "Planning for Tourism, Leisure and Sustainability: International case studies”, 2011, Anthony Travis, book review, for Journal of Sustainable Tourism.

Iankova, K. and Mileva, S. (n.d.), The destiny of the communist heritage of Bulgaria and its integration in the tourism industry, working paper, available at: researchgate.net (accessed 27 February 2017).

Ivanov S. (2009), "Opportunities for developing communist heritage tourism in Bulgaria", Tourism Review, Vol. 57 No 2 p. 177-192.

Ivanova, M. (2017), “The inclusion of the communist/socialist heritage in the emerging representations of Eastern Europe: the case of Bulgaria", Tourism, Culture and

Communication, Vol. 14, pp. 47-59.

Jenkins, K. (1995), On 'What is history?' From Carr and Elton to Rorty and White, Routledge, London.

Judd, D. (1995), "Promoting tourism in US cities", Tourism Management. Vol. 16 No. 3, pp. $175-187$.

Keats, D. M. (2000), Interviewing: a practical guide for students and professionals, Open University Press, Buckingham.

Kolbe, L. (2007), “Central and Eastern European capital cities: interpreting www-pages history, symbols and identity", Planning Perspectives, Vol. 22 No. 1, pp. 79-111.

Kotler, P., Haider, D., Rein, I. (1993), Marketing Places - Attracting investment, industry, and tourism to cities, states, and nations, The Free Press, New York.

Kuusi, H. (2008), "Prison Experiences and socialist sculptures - tourism and the soviet past in Baltic states", Kostiainen, A. and Syrjamaa, T. (eds), Touring the past uses of history in tourism, FUNTS, Savonlinna, Finland.

Li, Y., \& Hu, Z. (2008), "Red tourism in China”, Journal of China Tourism Research, Vol. 4 No. 2, pp. 156-171. 
Li, Y., Hu, Z.Y. and Zhang, C.Z. (2010), "Red Tourism: Sustaining Communist Identity in a rapidly Changing China", Journal of Tourism and Cultural Change. Vol. 8 No 1-2, pp. 101119.

Light, D. and Dumbraveanu, D. (1999), "Romanian tourism in the post-communist period", Annals of Tourism Research, Vol. 26 No. 4, pp. 898-927.

Light, D. (2000a), “An Unwanted Past: contemporary tourism and the heritage of communism in Romania", International Journal of Heritage Studies, Vol. 6 No. 2, pp. 145 160.

Light, D. (2000b), "Gazing on communism: heritage tourism and post-communist identities in Germany, Hungary and Romania”, Tourism Geographies, Vol. 2 No. 2, pp. 157-176.

Light, D. (2001), “'Facing the future': tourism and identity - building in post-socialist Romania”, Political Geography, Vol. 20, pp. 1053-1074.

Light, D. and Young, C. (2011), "Socialist Statuary as Post-Socialist Hybrids: Following the Statues of Dr. Petru Groza in Romania”, Journal of Historical Geography, Vol. 37, pp.493501.

Lowenthal, D. (1995), The past is a foreign country, Cambridge University Press, Cambridge.

Maitland, R. (2010), Tourism and changing representation in Europe's historic capitals, available at: http://www.ledonline.it/Rivista-Scienze-Turismo/Allefati/RST-I-2-07Maitland.pdf (accessed 2 February 2011).

Marsh, B. (2012), The legacy of communism in CEE, E-International Relations, http://www.e-ir.info/2012/05/23/the-legacy-of-communism-in-cee/ (accessed 27 February 2017).

Matei, E. (2011), "Udrea wants to make money off Ceausescu / Udrea vrea sa faca bani de pe urma lui Ceausecu”, Libertatea Online, 18 August 2011, available at:

$<$ http://www.libertatea.ro/detalii/articol/udrea-vrea-sa-faca-bani-de-pe-urma-lui-ceausescu350523.html> (accessed 20 March 2012).

NewsIn (2011), "Elena Undrea's red tourism should include the former communist concentration camps and the headquarters of the securitate / Circuitul rosu al Elenei Udrea ar trebui sa include fostele lagare si sediile securitatii”. Ziare/Papers, 18 August 2011 at 22:04, available at: $<$ http://www.ziare.com/udrea/ministrul-dezvoltarii-si-turismului/circuitul-rosu- 
al-elenei-udrea-ar-trebui-sa-includa-fostele-lagare-si-sediile-securitatii-1114898> [accessed 20 March 2012].

Park, H., Y. (2014), Heritage Tourism, Routledge, London.

Pritchard, A., Morgan, N.J. (2001), "Culture, identity and tourism representation: marketing Cymru or Wales?”, Tourism Management, Vol. 22, pp.167-179.

Ratz, T., Smith, M., Michalko, G. (2008), "New places in old spaces: Mapping tourism and regeneration in Budapest”, Tourism Geographies, Vol. 10 No. 4, pp. 429-451.

ReclameVechiRomanesti (2017), OldRomanianAds, Facebook page, available at:

https://www.facebook.com/ReclameVechiRomanesti.OldRomanianAds/?pnref=story (accessed 15 June 2017).

Richards, G. (2007), Cultural tourism: Global and local perspectives, Haworth Press, New York.

Richardson, J., I. and Fluker, M. (2004), Understanding and managing tourism, Pearson, Frenchs Forest.

RoNTO (2009), “Bucharest, Romanian Tourist Office”, Ministry for Tourism, printed brochure.

Sandbox Networks Inc. (2017), Communist countries, past and present, available at: http://www.infoplease.com/ipa/A0933874.html (accessed 27 February 2017).

Sima, C. (2013), Post-communist capital city representation: case-study Bucharest, University of Westminster, $\mathrm{PhD}$ thesis, unpublished, available at: http://westminsterresearch.wmin.ac.uk/12571/1/Claudia_SIMA.pdf, (accessed 11 December 2016).

Smith, M. and Puczko, L. (2012), "Budapest: from socialist heritage to cultural capital", Current Issues in Tourism, Vol. 15 No.1/2, pp. 107-119.

Stern, B. B. and Schroeder, J. E. (1994), "Interpretative methodology from art and literary criticism: a humanistic approach to advertising imagery", European Journal of Marketing, Vol. 28 No. 8-9, pp. 114-132.

Suvantola, J. (2002), Tourist's experience of place (New directions in tourism analysis), Ashgate Publishing, Aldershot. 
Stanilov, K. (2007), The post-socialist city: Urban form and space transformations in Central and Eastern Europe after socialism, Springer, London.

Todorova M., Gille, Z. (2013), Post-communist nostalgia, Berghahn Books.

Todorova, M., Dimou, A., Troebst, S. (2014), Remembering communism: Private and Public Recollections of Lived Experience, Central European University Press.

Urry, J (1990), The tourist gaze: Leisure and travel in contemporary societies, Sage Publications, London.

Ward, S. V. (1998), Selling places - The marketing and promotion of towns and cities 18502000, Routledge, London.

Zhao, S. N. and Timothy, D. J. (2015), "Governance of red tourism in China: Perspectives on power and guanxi”, Tourism Management, Vol. 46, pp. 489-500.

Zhao, S. N. and Timothy, D. J. (2017), “Tourists' consumption and perceptions of red heritage", Annals of Tourism Research, Vol. 63, pp. 97-111.

Zubak, M. (2005), “The Croatian spring: Interpreting the communist heritage in postcommunist Croatia”, East Central Europe/L'Europe du Centre-Est, Vol. 32 No. 1-2, pages pp. 191-225. 
Figure 1. The relationship between communist heritage tourism in CEE and red tourism in East Asia and China

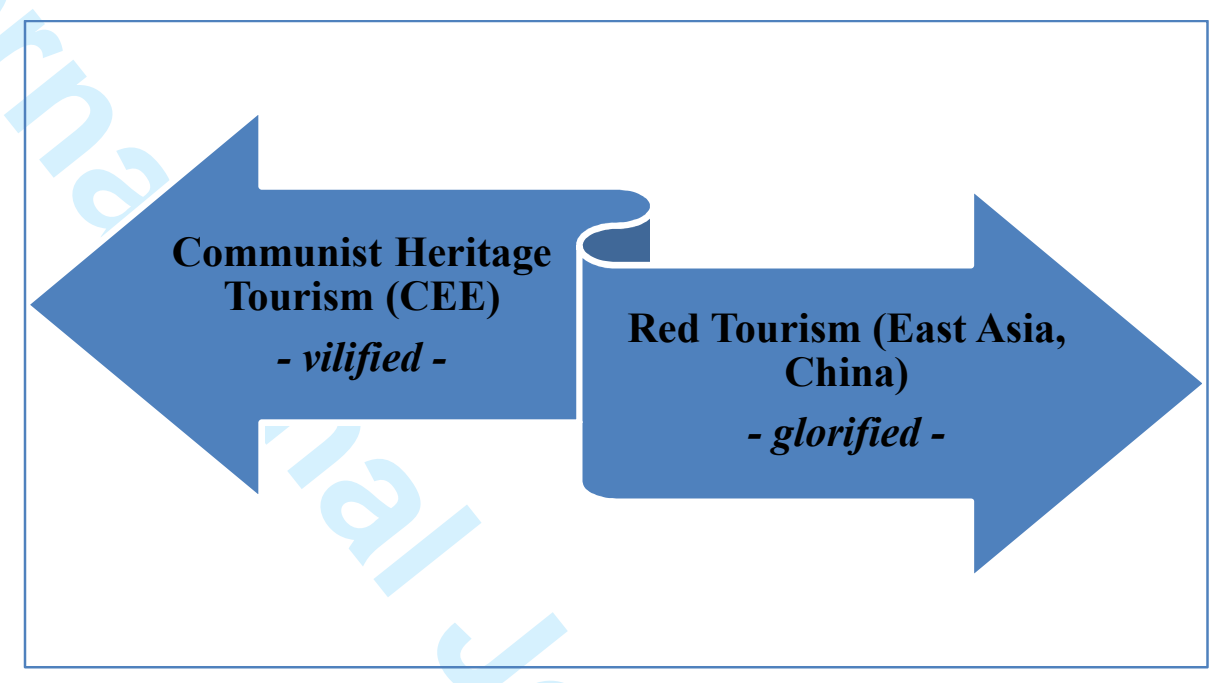


Table 1. The geographical distribution of communist heritage

\begin{tabular}{|c|c|}
\hline Relationship with communism & Countries \\
\hline Current communist countries & China, Cuba, Laos, North Korea, Vietnam \\
\hline \multicolumn{2}{|l|}{$\begin{array}{l}\text { Formerly communist countries } \\
\text { (by current name) }\end{array}$} \\
\hline $\begin{array}{l}\text { - Formerly part of the } \\
\text { Soviet Union }\end{array}$ & $\begin{array}{l}\text { Armenia, Azerbaijan, Belarus, Estonia, Georgia, } \\
\text { Kazakhstan, Kyrgyzstan, Latvia, Lithuania, Moldova, } \\
\text { Russia, Tajikistan, Turkmenistan, Ukraine, Uzbekistan }\end{array}$ \\
\hline - Other Asian countries & Afghanistan, Cambodia, Mongolia, Yemen \\
\hline $\begin{array}{l}\text { Soviet-controlled Eastern } \\
\text { Bloc countries }\end{array}$ & $\begin{array}{l}\text { Bulgaria, Czech Republic, (East) Germany, Hungary, } \\
\text { Poland, Romania, Slovakia }\end{array}$ \\
\hline - The Balkans & $\begin{array}{l}\text { Albania, Bosnia and Herzegovina, Bulgaria, Croatia, } \\
\text { Republic of Macedonia, Montenegro, Serbia, Slovenia }\end{array}$ \\
\hline - Africa & $\begin{array}{l}\text { Angola, Benin, Democratic Republic of Congo, } \\
\text { Ethiopia, Somalia, Eritrea, Mozambique }\end{array}$ \\
\hline
\end{tabular}

Source: Sandbox Networks (2017) 
Figure 2. The spectrum of communism related heritage tourism classified according to dominant feelings

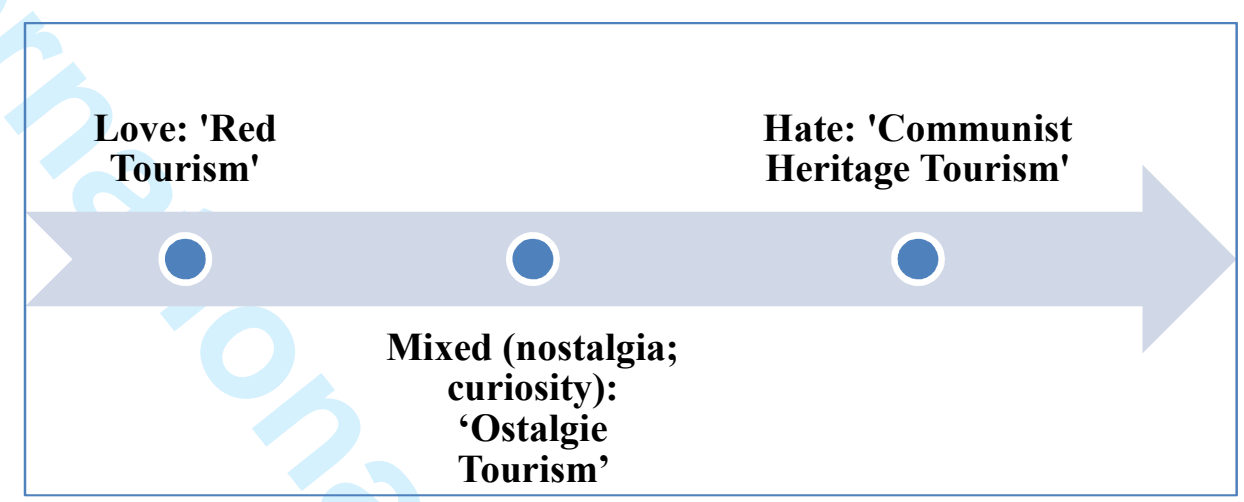

19

20

21

22

23

24

25

26

27

28

29

30

31

32

33

34

35

36

37

38

39

40

41

42

43

44

45

46

47

48

49

50

51

52

53

54

55

56

57

58

59

60 
Table 2. Differences between 'red tourism; and 'communist heritage tourism'

\begin{tabular}{|c|c|c|}
\hline Domain & Red Tourism & Communist Heritage Tourism \\
\hline $\begin{array}{l}\text { Region/ } \\
\text { Countries }\end{array}$ & $\begin{array}{l}\text { Current and former communist } \\
\text { countries (for example, People's } \\
\text { Republic of China) }\end{array}$ & $\begin{array}{l}\text { Former communist countries } \\
\text { Central and Eastern Europe (for } \\
\text { example, (East) Germany; } \\
\text { Romania; Hungary; Bulgaria) }\end{array}$ \\
\hline Emergence & After 2004 & After 1990 \\
\hline $\begin{array}{l}\text { Development/ } \\
\text { Evolution }\end{array}$ & $\begin{array}{l}\text { Planned by the State (for example, in } \\
\text { China it is planned and developed by } \\
\text { the Chinese Communist } \\
\text { Government) }\end{array}$ & $\begin{array}{l}\text { External demand (for example, } \\
\text { western tourists) } \\
\text { Internal demand (for example, } \\
\text { locals or residents from the same } \\
\text { country) }\end{array}$ \\
\hline $\begin{array}{l}\text { Types of } \\
\text { tourism }\end{array}$ & $\begin{array}{l}\text { Mass \& niche/special interest } \\
\text { tourism (culture and heritage): } \\
\text { National Heritage Tourism (for } \\
\text { example 'patriotic tourism' in China) }\end{array}$ & $\begin{array}{l}\text { Niche/special interest: } \\
\text { Heritage tourism; } \\
\text { Nostalgic tourism (for example: } \\
\text { 'ostalgie tourism' in East Germany) }\end{array}$ \\
\hline Heritage sites & $\begin{array}{l}\text { Related to the Chinese communist } \\
\text { revolution and its legacy }\end{array}$ & $\begin{array}{l}\text { Related to communist regimes, their } \\
\text { downfall and legacy }\end{array}$ \\
\hline $\begin{array}{l}\text { Heritage } \\
\text { interpretation }\end{array}$ & $\begin{array}{l}\text { Positive: Glorifying the communist } \\
\text { past and present }\end{array}$ & $\begin{array}{l}\text { Negative: Negative views of the } \\
\text { communist period }\end{array}$ \\
\hline Main target & $\begin{array}{l}\text { Chinese young people (pupils, } \\
\text { students) } \\
\text { Families } \\
\text { Cultural tourists } \\
\text { Nationalists and Patriots }\end{array}$ & $\begin{array}{l}\text { Westerners - people that lived } \\
\text { outside the Iron Curtain (for } \\
\text { example, Baby Boomers and } \\
\text { Generation X British tourists) } \\
\text { Easterners (for example, Chinese } \\
\text { tourists) } \\
\text { Locals } \\
\text { Residents }\end{array}$ \\
\hline
\end{tabular}




\begin{tabular}{|c|c|c|}
\hline Education & $\begin{array}{l}\text { Very important - inform and educate } \\
\text { on the achievements and benefits of } \\
\text { communism for the society (for } \\
\text { example, stimulate nationalist spirit } \\
\text { and patriotism towards the Chinese } \\
\text { Communist Party) }\end{array}$ & $\begin{array}{l}\text { Tendency to ignore, forget the } \\
\text { communist past so the educational } \\
\text { side of tourism is not well } \\
\text { represented. }\end{array}$ \\
\hline Purpose & Glorifying the communist past & $\begin{array}{l}\text { Recreation, expanding cultural } \\
\text { horizons } \\
\text { Remembrance, nostalgia }\end{array}$ \\
\hline Problems & $\begin{array}{l}\text { Heritage interpretation - } \\
\text { 'Disneyfication' }\end{array}$ & $\begin{array}{l}\text { Heritage interpretation - 'dissonant } \\
\text { heritage' }\end{array}$ \\
\hline
\end{tabular}

Source: Adapted from Light (2000a; 2000b); Caraba (2011:37); Zhao and Timothy (2014; 2017). 
Table 3. Overview of data collection and analysis methods

Objective 1. How do textual and visual destination materials and user generated content represent Bucharest in terms of communist and revolution heritage tourism and are there any differences in perceptions and representations?

Method/Stage 1. Content analysis of textual $\quad$ Method/Stage 2. Content analysis of tourist and visual destination materials produced by blogs (text, picture) government, industry and media How many: 54

How many: 105 Location: online

Location: online

Objective 2. Why do these destination representations of communist and revolution heritage tourism exist and what factors shape and affect them?

Method/Stage 3. Semi-structured in-depth interviews with tourism professionals; a sample of: Government; Industry; Media How many: 42 Location: London, Bucharest
Method/Stage 4. Focus-groups with potential tourists to Bucharest (textual and picture elicitation was employed)

How many: 3 focus-groups, 18 participants Location: London 
Table 4. Gaps in the representations of communist and revolution heritage tourism in Bucharest

\begin{tabular}{|c|c|}
\hline Type of gap & Definition \\
\hline Gap 1 - Perception gap & $\begin{array}{l}\text { Each actor perceives the communist and revolution heritage } \\
\text { of Bucharest in different, contradictory, and opposing ways } \\
\text { - Government - perceiving it as 'problematic'; aware } \\
\text { of the differences in opinion between tourists and } \\
\text { locals } \\
\text { - Industry - perceiving it as valuable } \\
\text { - Media - perceiving it as interesting } \\
\text { - Tourists - perceiving it as interesting, an addition to } \\
\text { - their experience } \\
\text { - Potential tourists - perceiving it as worth visiting }\end{array}$ \\
\hline Gap 2 - Emotional gap & $\begin{array}{l}\text { There are differences in how different actors feel about } \\
\text { communist and revolution heritage tourism } \\
\text { - Government - fearful, cautious } \\
\text { - Industry - happy } \\
\text { - Media - entertained } \\
\text { - Tourists - fascinated } \\
\text { - Potential tourists - curious }\end{array}$ \\
\hline Gap 3 - Action gap & $\begin{array}{l}\text { There is a gap between awareness of the potential of } \\
\text { communist and revolution heritage tourism and actually } \\
\text { acting on it } \\
\text { - Government - not doing anything about it officially } \\
\text { - Industry - commercialising it; selling it } \\
\text { - Media - acknowledging it; unofficially promoting it } \\
\text { - Tourists - experiencing it } \\
\text { - Potential tourists - planning to see it }\end{array}$ \\
\hline
\end{tabular}

